\title{
Development of Digital University Model in Modern Conditions: Institutional Approach
}

\section{Elvir Munirovich Akhmetshin}

elvir@mail.ru

Kazan Federal University, Elabuga Institute of KFU, Russia

\section{Vladimir Lvovich Vasilev}

vlvasilev80@mail.ru

Kazan Federal University, Elabuga Institute of

KFU, Russia

\author{
Artemiy Vladimirovich Kozachek \\ artem_kozachek@mail.ru \\ Tambov State Technical University, Russia
}

\section{Galina Vladimirovna Meshkova}

gvmeshkova@inbox.ru

Bauman Moscow State Technical University,

Russia

\author{
Maria Vladimirovna Mikhailova \\ mvmikhailova@bk.ru \\ Sechenov First Moscow State Medical \\ University, Russia
}

\begin{abstract}
Currently, special attention is paid to the development of digital technologies. In the context of the pandemic, the remote, distance, digital format of work has become top requested. Those events coincided with the general trend towards total digitalization of all spheres of life, including education. New concepts have emerged and taken hold - digital education and digital university. However, a mechanism for the development of a digital university has not yet been proposed. In the present study, an institutional approach was used to analyze the problems of the development of a digital university. The research scheme was used: institutions - motivation - control. The results of the empirical study (questionnaire and survey of university entries and its partners) made it possible to identify the existing contradictions between the participants in university activities and the external environment in terms of assessing aspects of the digital development of the university, to highlight the most effective institutions, conditions of positive motivation and control mechanisms for successful digital transformation of a university. The authors propose their own version of the concept for the development of a digital university, introducing as the core of it a new scientific concept - infrastructure logic. They lay a foundation for the principles of infrastructure logic, formation mechanisms and approaches to the use of indicators of digital development based on infrastructure logic, directions for improving the strategy of digital development of the university 4.0. The conclusions and recommendations formulated in this study can be used by other educational systems and universities.
\end{abstract}

\section{Keywords}

institutions; motivation; infrastructure logic; education; digital development; university 4.0; indicators of digital development; external environment 


\section{Introduction}

Currently, digital technologies are being actively introduced in all spheres of human life, including education. Modern universities have approached the task of transition to the University 4.0 model or to the digital university model. A deep historiographic analysis and a review of scientific literature on the topic of university evolution has shown that modern universities have a special digital ecosystem with a specific structure, functions and elements. For each university model (1.0, $2.0,3.0,4.0)$, there is a set of key resources that allow these models to function effectively. A distinctive feature of the modern digital university model is a digital platform, to which all the university subjects have access. All traditional functions of the university are transformed with the help of digital technologies, acquiring a new quality and a new implementation format. This primarily concerns educational activities. The intelligent system of a digital university, collecting "clean data" about a student, accumulates his digital footprint and can recommend an individual educational trajectory (Díaz and Boj, 2019). This, in turn, requires certain bases of digital educational resources and digital management of teachers' time and availability. Wages and funding for universities are also changing with the increasing activity of private capital towards distance learning technologies (Ferlie and Trenholm, 2019).

In the same way, the research activity of the university is changing, which is currently aimed at integrating with the real sector of the economy through practice-oriented scientific research. The specificity of the current stage is using digital technologies, quantum computers and artificial intelligence to perform such research. Any processes, even complex ones, social, economic, physical, chemical, physiological (in the human body) can be simulated (Zelentsova, 2018; 2020). The digital university implements these tasks through interaction with ministries and departments, partner enterprises, where it organizes basic departments and practice facilities, and also creates "mirror" broadcast laboratories and a circle of small innovative enterprises (Perez Gama et al., 2018).

Thus, the world has entered the digital era, in which university education and science are changing, acquiring new priorities, forms of implementation, conditions of use. A new digital university model is being formed. An urgent task is to study it and identify development prospects.

\section{Literature review}

A modern university should have built-in mechanisms for adaptive response to global challenges. This can be provided by digital technologies that allow increasing the rate of management decision making, automating long routine procedures, making paper workflow instant electronic one (Barabanova et al., 2019).

All modern universities are beginning to develop their digital platform and digital infrastructure, highlighting the functionality of an applicant, student, teacher, researcher, other types of personnel, university partners, representatives of the real sector of the economy (Crittenden et al., 2019).

Usually, there are two circuits for processing and movement of information: internal electronic document flow and external interaction in a digital environment. This approach ensures the fastest possible reaction of the university management system to emerging market changes and threats (Irodov and Korechkov, 2018; Semenov, 2021).

During the formation of the digital platform and digital infrastructure of a university, considerable attention is paid to the protection of personal data. Currently existing information security technologies allow for this (Nurgaliev et al., 2019; Korableva et al., 2019). 
Modern strategies for the development of universities are aimed at ensuring world-class competitiveness. At the same time, global trends in the increasing role of digital technologies should be taken into account. The strategy is based on target indicators ensuring high world competitiveness ranking. These rating systems are: Webometrics, QS, THE (Mukhomorova et al., 2020).

The grouping of universities according to comparable criteria allows identifying the key factors in the growth of a university's competitiveness. On the one hand, the indicators of the digital development of universities are compared: the number of open online courses, the number of downloads on the Internet to the official website, the number of citations of teachers' articles in electronic databases. On the other hand, the position of a university in world ranking systems is assessed. By calculating the correlation coefficient, the relationship between the indicators of digital development and the final ratings of the university is revealed. Recent studies have shown that a high position in world competitiveness ranking systems is provided by such factors as the reputation of the university, citation of teachers, the number of articles in the ResearchGate database (Safiullin et al., 2019).

After identifying the key performance indicators of a modern university, a decision is made to adjust its strategy. As the literature review has shown, the main directions of development of modern universities are associated with the expansion of the use of digital technologies (Bolgova et al., 2020; Evans-Amalu and Claravall, 2021; Williams et al., 2021; Demichev, 2021).

Analysis of world trends and the most well-known indicator systems of the World Economic Forum (WEF), World Intellectual Property Organization (WIPO), Organization for Economic Cooperation and Development (OECD), Statistical Bureau of the European Community (Eurostat), Federal State Statistics Service of the Russian Federation, Higher School economy (NRU HSE) and a number of international news agencies, has also shown a focus on assessing resources specific to digital development: intellectual property and objects of innovation infrastructure (Yli-Viitala et al., 2020). The fact is that the generally recognized rankings of competitiveness of universities Quacquarelli Symonds (QS) World University Rankings; Times Higher Education (THE) World University Rankings; "Webometrics" (Ranking Web of Universities); Academic Ranking of World Universities (ARWU) do not fully assess the indicators of digital development of an educational organization.

Nevertheless, the decision on the financial support of the university by the state and private investors is made on the basis of precisely the generally recognized ratings. The choice of an applicant can also be based on the results of such ratings. On the other hand, all top-ranked universities tend to actively work on their digital development. It is safe to conclude that by measuring and improving the indicators of digital development in the modern world, with a high degree of probability, the university will improve its position in the generally recognized ratings of competitiveness. The literature objectively notes a trend of simultaneous improvement in the overall performance indicators of a university and its digital development indicators (Baumol and Bockshecker, 2017).

Thus, the literature review shows the high relevance of research on the problems and prospects of digital development of universities. There are many approaches to the formation and development of the digital university model. However, the conditions of digital interaction of the new model of the university and the external environment have not been sufficiently studied. It is obvious that such interaction will also require modernization of the internal processes of a university and its partners. A coordinated restructuring of well-established rules (institutions) will be needed to ensure effective digital interaction. Without institutional preparation of the university and its partners, it will be impossible to launch a new digital university model.

An important aspect here is the problem of the formation of indicators of the efficiency and competitiveness of the digital development of University 4.0 under the influence of external 
environment factors. Unfortunately, today there is no such mechanism for the transition of universities to a digital model that can take into account the need and rules for the formation of new indicators of a university's performance that meet such requirements. Therefore, the purpose of this study is to develop such a mechanism, as well as to identify the most effective institutions (interaction rules) of all subjects of an educational institution and its partners in the context of the development of a digital university model.

\section{Research methods}

The authors propose to use an institutional approach to the formation of a mechanism for the development of a digital university. According to one of the founders of institutional theory, Neil Fligstein (1996), the rules of the game in the market and in all social interactions create a certain motivation. At the same time, both the rules of the game and motivation are supported by control mechanisms (Fig. 1).

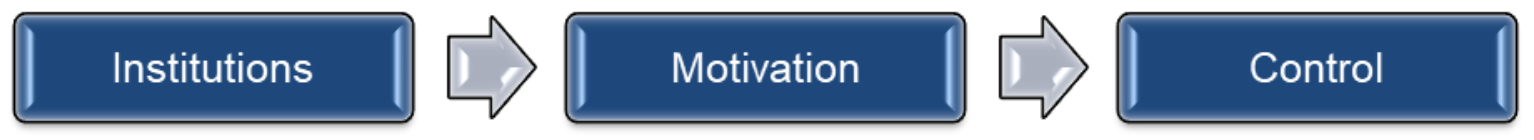

Fig. 1. A chain of the institutional mechanism for ensuring digital transformation

Source: (Fligstein, 1996).

An important takeaway from this diagram is that certain motives require certain institutions and control mechanisms. If the appropriate institutions and control mechanisms are not created, the necessary motivation will not arise. Subjects of digitalization without the necessary institutional support will not be motivated for an effective process of digitalization of the university.

This thesis is confirmed by the Nobel laureate in the field of institutional theory - Douglas North. He writes: "Institutions create the basic structures by which people throughout history have achieved order and thus reduced their insecurity" (North, 2012). First of all, it is necessary to investigate the motives and required rules for the interaction of subjects of digitalization and on this basis move to the process of the university digitalization.

The Russian scientist - institutionalist A.N. Nesterenko notes: "Institutions initially arise on the basis of human instincts and simplest needs, contributing to their satisfaction, they acquire a selfsustaining nature and, based on the feedback principle, form stereotypes of thinking" (Nesterenko, 1997). It is necessary to ensure the self-sustaining nature of the digitalization process, which is only possible if the motives of the digitalization subjects and the program of events for the digital development of the university coincide (Vasiliev, 2014).

Digital interaction institutions are a set of formal and informal rules allowing the subjects of a university and its partners to organize and conduct their mutually beneficial activities in the socioeconomic environment. The authors of the article set the task of applying this methodological approach to determine the optimal motives, institutions and control mechanisms for digitalization subjects at a university. Previously, this technique was successfully used to solve the problem of developing innovative entrepreneurship in the education system of the Russian economy (Vasiliev, 2014).

The research hypothesis: The problem of digital development of a university is associated with the inconsistency of the existing institutional chain (institutions - motivation - control) with the tasks of 
digital development. The tasks of digital development require the modernization of institutions (rules of interaction between the subjects of a university and its partners), which will contribute to the formation of the necessary motivation. At the same time, it is important to provide effective control mechanisms, which the authors of the article associate with a new concept of the digital age - infrastructure logic.

To confirm the research hypothesis, develop the authors' methodological recommendations, a questionnaire study and a survey were carried out.

A total of 195 people were interviewed. Of these: 100 people - students from 1 to 4 courses, both humanitarian and engineering fields of training; 50 people - teachers of the same areas of training; 10 people - administrative and management personnel responsible for making decisions and achieving key performance indicators of the university; 35 people - representatives of the university's partner companies, employers for university students, mainly middle-level managers, but participating in decision-making on staffing their enterprises, joint scientific and applied research with the university. To conduct a questionnaire and process the results of the survey, consent was collected from all participants in the experiment. The law on the retention of personal data and the right to maintain privacy have not been violated. The sampling error was $5 \%$. The questions of the questionnaire are given in Table 1:

\begin{tabular}{|c|c|}
\hline Question formulation & Answer options \\
\hline 1. What are you: & $\begin{array}{l}\text { A) a student } \\
\text { B) a teacher } \\
\text { C) a representative of administrative and management } \\
\text { personnel } \\
\text { D) a representative of the real sector of economy }\end{array}$ \\
\hline $\begin{array}{l}\text { 2. What are the main reasons } \\
\text { preventing the active } \\
\text { introduction of digital } \\
\text { technologies at the university? }\end{array}$ & $\begin{array}{l}\text { A) difficulties in mastering everything new, unknown } \\
\text { B) difficulties in managing a team using digital technologies } \\
\text { C) increase in work due to duplication of paper and electronic } \\
\text { documents } \\
\text { D) increasing risks of digital fraud } \\
\text { E) difficulties in processing information and its conversion } \\
\text { (significant growth in the volume of information, "information } \\
\text { noise") } \\
\text { F) discrepancy between wages and work volumes with digital } \\
\text { technologies }\end{array}$ \\
\hline $\begin{array}{l}\text { 3. What do you think are the } \\
\text { most important requirements } \\
\text { for the organization of digital } \\
\text { processes at the university? }\end{array}$ & $\begin{array}{l}\text { A) automation of routine work (drawing up work programs, } \\
\text { assessment tool stocks, reports on the studies and the results } \\
\text { of research activities, planning the workload) } \\
\text { B) elimination of duplication of paper and electronic media } \\
\text { C) increase in wages when working with digital technologies } \\
\text { D) harmonization of digital environments of the university and } \\
\text { external organizations (enterprises) } \\
\text { E) formation of uniform requirements for digital and } \\
\text { professional competencies of a graduate (the ability to quickly } \\
\text { adjust these requirements) } \\
\text { F) protection of personal data } \\
\text { G) improving the material and technical base and } \\
\text { technological equipment of the university }\end{array}$ \\
\hline
\end{tabular}




\begin{tabular}{|l|l|}
$\begin{array}{l}\text { 4. Check out the most needed } \\
\text { activities to develop the digital } \\
\text { university model }\end{array}$ & $\begin{array}{l}\text { A) improving the university development strategy by including } \\
\text { digital development targets } \\
\text { B) identifying the requirements of all the university subjects } \\
\text { (students, teachers, innovators, researchers, administrative } \\
\text { and managerial personnel, representatives of government } \\
\text { ministries and departments, representatives of local } \\
\text { authorities and the real sector of the economy) and } \\
\text { developing uniform priorities for digital development } \\
\text { C) the formation of systematic measures for the } \\
\text { implementation of the digital university model } \\
\text { D) organization of work to attract investment resources to the } \\
\text { university from state funds (targeted programs, national } \\
\text { projects) and (or) from private investors } \\
\text { E) the introduction of the digital university model is only } \\
\text { possible after ensuring certain external conditions (the } \\
\text { transition of the entire economy and society to a new model of } \\
\text { digital interaction) }\end{array}$ \\
\hline
\end{tabular}

Table 1: Questionnaire for identifying the optimal composition and structure of motives, institutions and control mechanisms

Source: developed by the authors.

Based on the answers of the respondents, the analysis of the results was carried out using statistical research methods, graphs were drawn up to visually reflect the research results. During the survey, the authors made the necessary adjustments to the research results, as new facts were obtained.

In addition, general scientific research methods were used: analysis, synthesis, comparison, systematization and logical modeling.

\section{Results}

Currently, the issues of digitalization of a university are becoming especially relevant. They touch on both macro and microeconomic aspects. At the level of the national economy, it is important to provide training for the digital business and entrepreneurship sector. At the university level, it is important to ensure the process of developing digital competencies among teachers and students. These issues are interrelated and require solutions, first of all, the problem of optimal institutional support. The results of the author's approach for solving this problem are given below.

The authors surveyed a number of respondents in order to understand the existing contradictions in the system of forming a digital university model (Table 1). The survey showed the following results. Graph 1 shows the structure of university subjects who took part in the survey. 


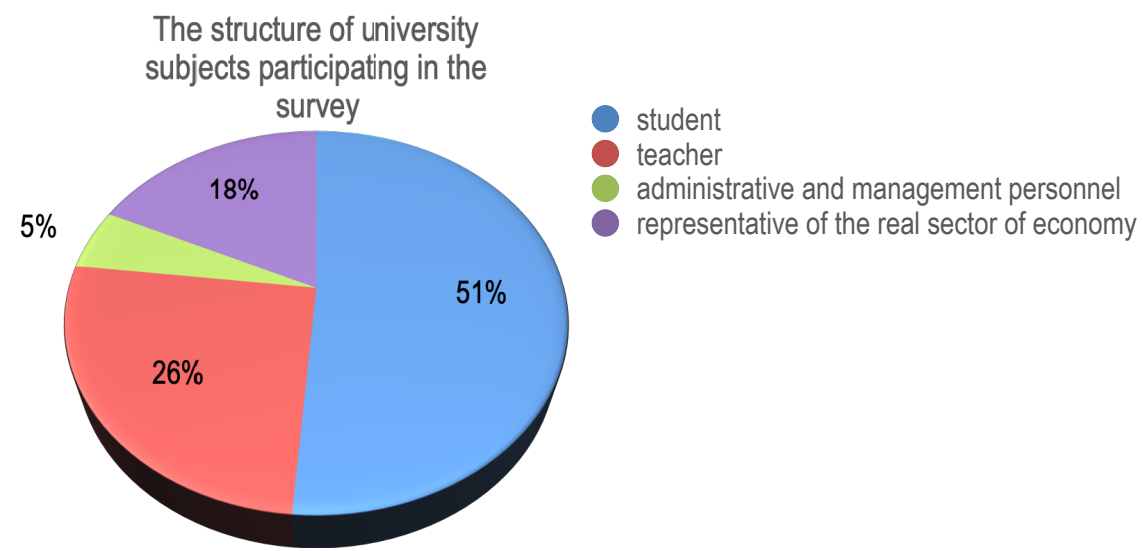

Graph 1. The structure of university subjects participating in the survey

The largest share in the survey belongs to students - $51 \%$. This is due to the fact that they are the main subjects of the educational process, for whom it is important to build an effective digital learning process. The share of teachers was $26 \%$. The teaching staff is responsible for the current results of using digital technologies. It is important to know what teachers think about the quality of the digital environment. Strategic decisions about the digital development of the university are made by administrative and managerial staff. Their share in the survey was $5 \%$. The main consumers of personnel and employers for students are representatives of business, the real sector of the economy. It is important to know their opinion on the necessary digital competencies of a future specialist and the conditions that form these digital competncies. The share of representatives of university partners was $18 \%$.

Graph 2 shows the results of answering the question about the main reasons that prevent the active implementation of digital technologies at the university.

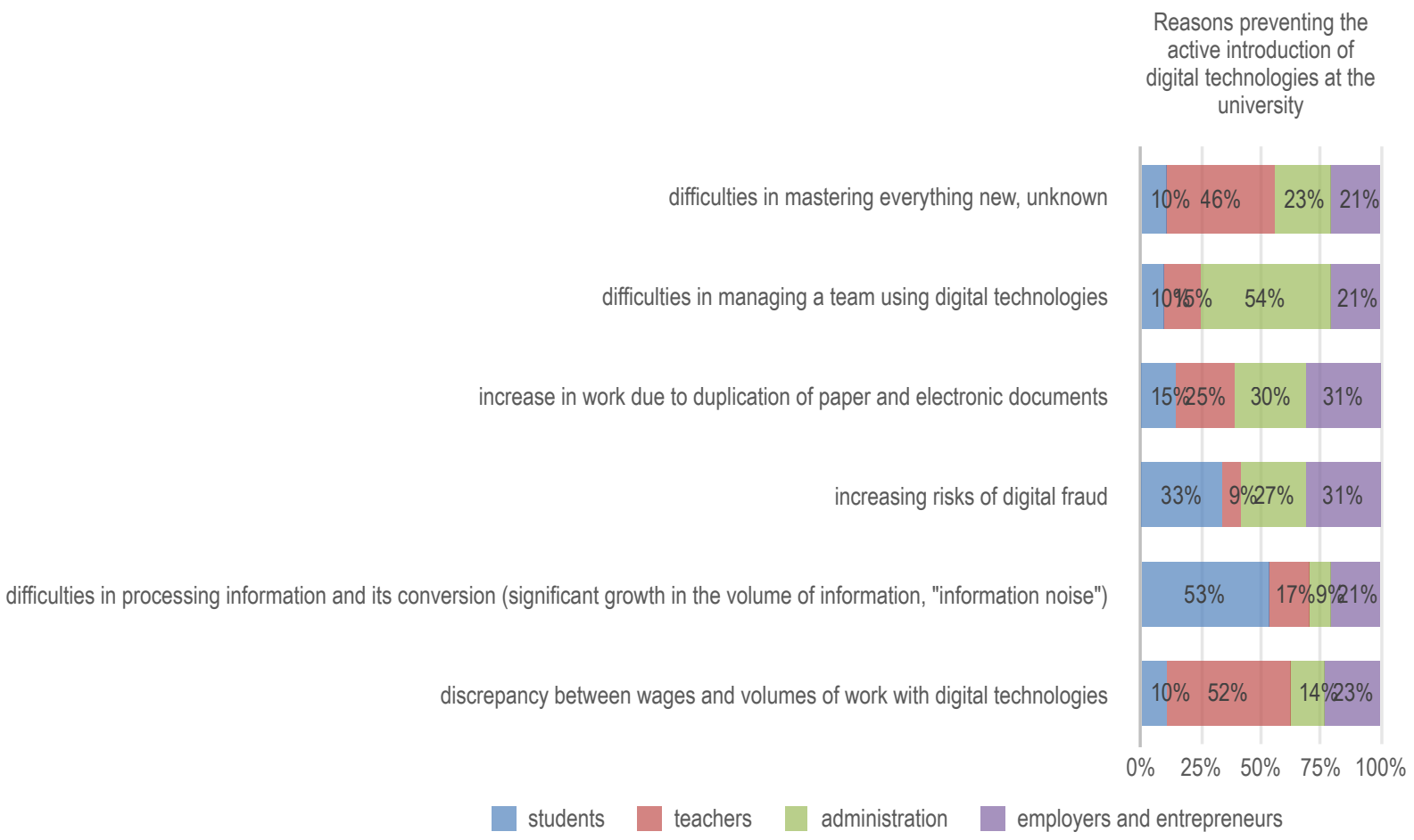

Graph 2. Reasons preventing the active introduction of digital technologies at the university

The majority of students (47\%) have attributed the difficulties of information processing in 
conditions of its constant growth to the main obstacle to the digital development of the university. Perhaps this was due to the beginning of obtaining a profession and the difficulties of modern education. At the same time, teachers, whose main job is to process information and find the necessary data from the entire volume of "information noise", do not consider this to be the main problem. The main problem, according to teachers, is the discrepancy between wages and the amount of work with digital technologies (36\%). The administration, which is responsible for the fairness of remuneration of labor functions of staff, sees the main problem in the difficulties of managing a team using digital technologies (33\%). It is obvious that outdated institutions (rules for managing personnel) do not coincide with modern requirements for the labor process, which are dictated by global digital development. At the same time, businesses are most concerned about the increasing risks of digital fraud (25\%). The digital age brings new risks, too. This must be taken into account when forming a digital university model.

Graph 3 shows the results of answering the question what are the most important requirements for the organization of digital processes at the university:

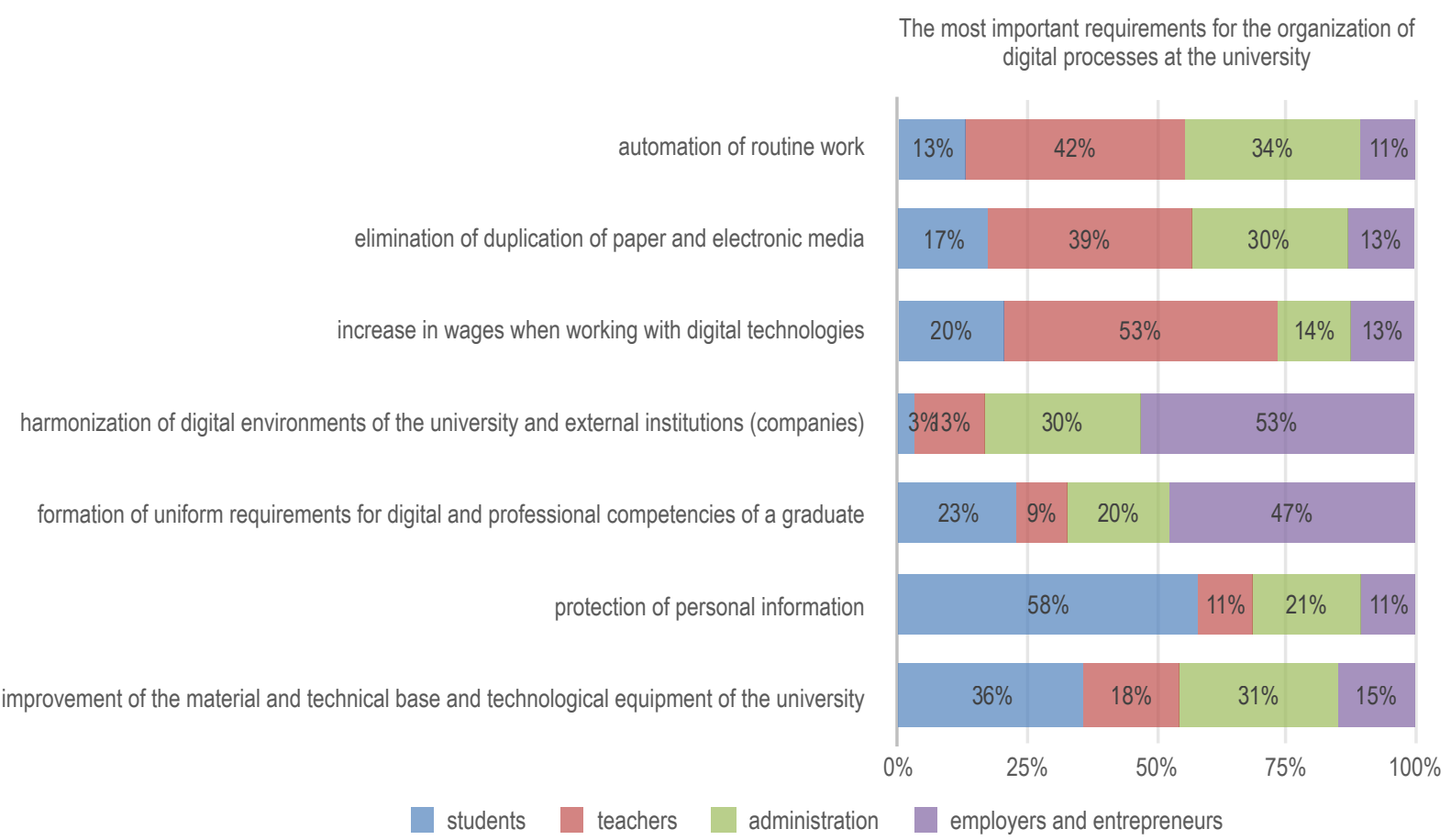

Graph 3. The most important requirements for the organization of digital processes at the university

According to students, personal data protection is becoming the most important in the digital age. $33 \%$ of all surveyed students answered this way. On the contrary, teachers noted this item as insignificantly important ( $6 \%$ of respondents). The main requirement of teachers is to raise wages when working with digital competencies (34\%). Administrative and managerial personnel see the main requirement in harmonizing the digital environments of the university and external institutions (companies) - 18\% of the respondents, and in improving the material and technical base and technological equipment of the university - $19 \%$ of the respondents. For business it is important to ensure the formation of uniform requirements for digital and professional competencies of a graduate (the ability to quickly adjust these requirements) - $35 \%$ of respondents. As we can see, all groups of university subjects have conflicting requirements for the organization of the digital transformation of the university. It is necessary to establish a uniform institutional agreement.

Graph 4 shows the results of the answer to the question about the most necessary measures for 
the development of the digital university model to be carried out.

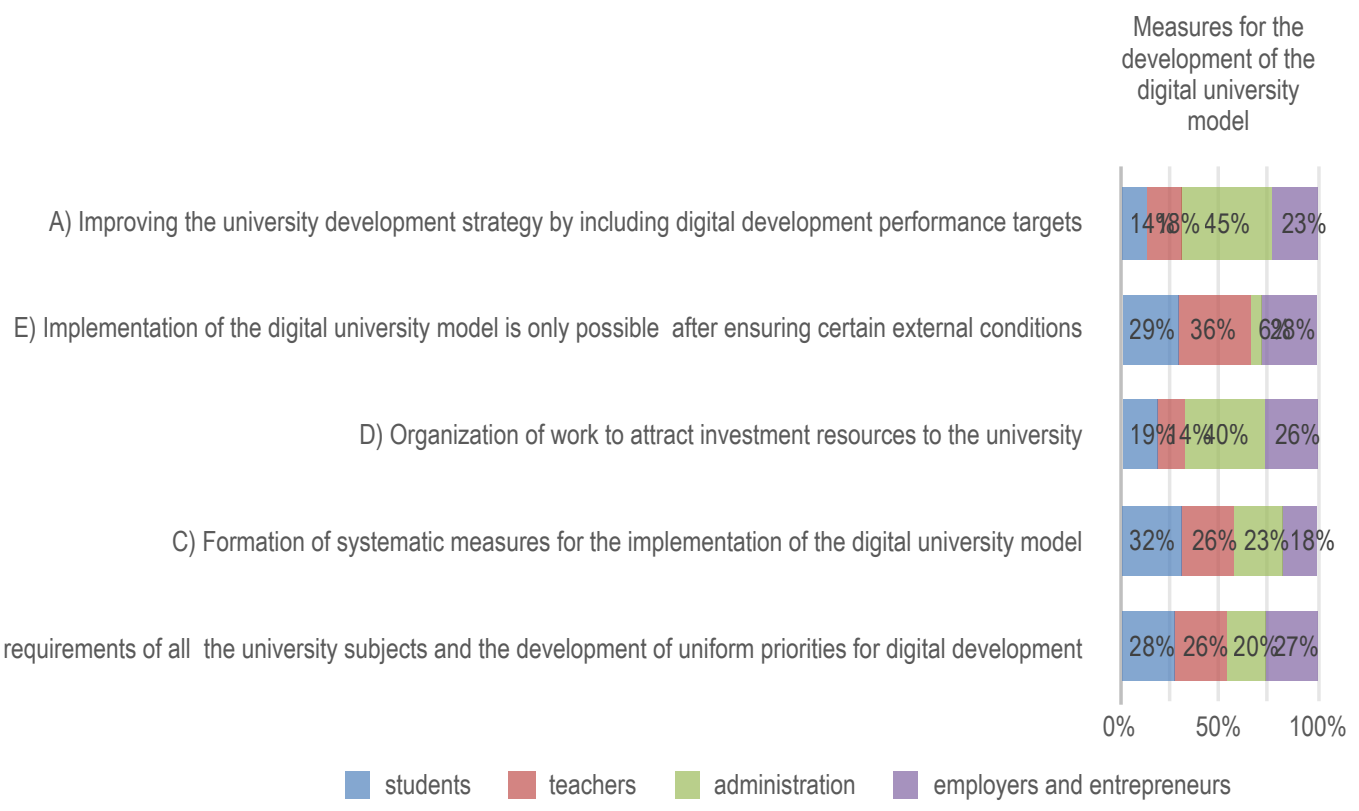

Graph 4. Measures for the development of the digital university model

Evaluating the discussion between the subjects of the university and its partners about possible measures for the development of the digital university model, one can also see the presence of contradictions. Thus, students consider as the key measure finding out the requirements of all participants in the educational process and the formation of a development strategy on this basis $(25 \%)$. Teachers believe that it is necessary to use a system approach to activities for the development of a digital university $(17 \%)$. The university administration considers the attraction of investment resources to modernize digital infrastructure to be the key measure (31\%). Along with this, the administration sees the prospect in improving the university's strategy by including the target indicators of digital development $(30 \%)$. This does not coincide in importance with the opinions of students $(9 \%)$, teachers $(12 \%)$ and business $(15 \%)$. On the contrary, students $(30 \%)$, as well as teachers (37\%) and business (29\%) (except for the university administration) believe that the implementation of the digital university model is possible only after ensuring certain external conditions (transition of the entire economy and society to a new digital interaction model).

Thus, the survey has shown a discrepancy between the interests of various subjects of the university and its partners. This situation leads to the emergence of conflicting motivations and actions for all participants in the digital transformation of the university. As a result, the authors have come to the conclusion that the existing institutions (rules of interaction) established in the field of higher education do not meet the requirements of digital development, allocated by various participants in university activities, as well as non-university activities, that is, subjects of the environment external to the university. Therefore, it is necessary to resolve this contradiction. For this, the authors'propose their own concept of the institutional mechanism for the transition to the digital university model (Fig. 2). 


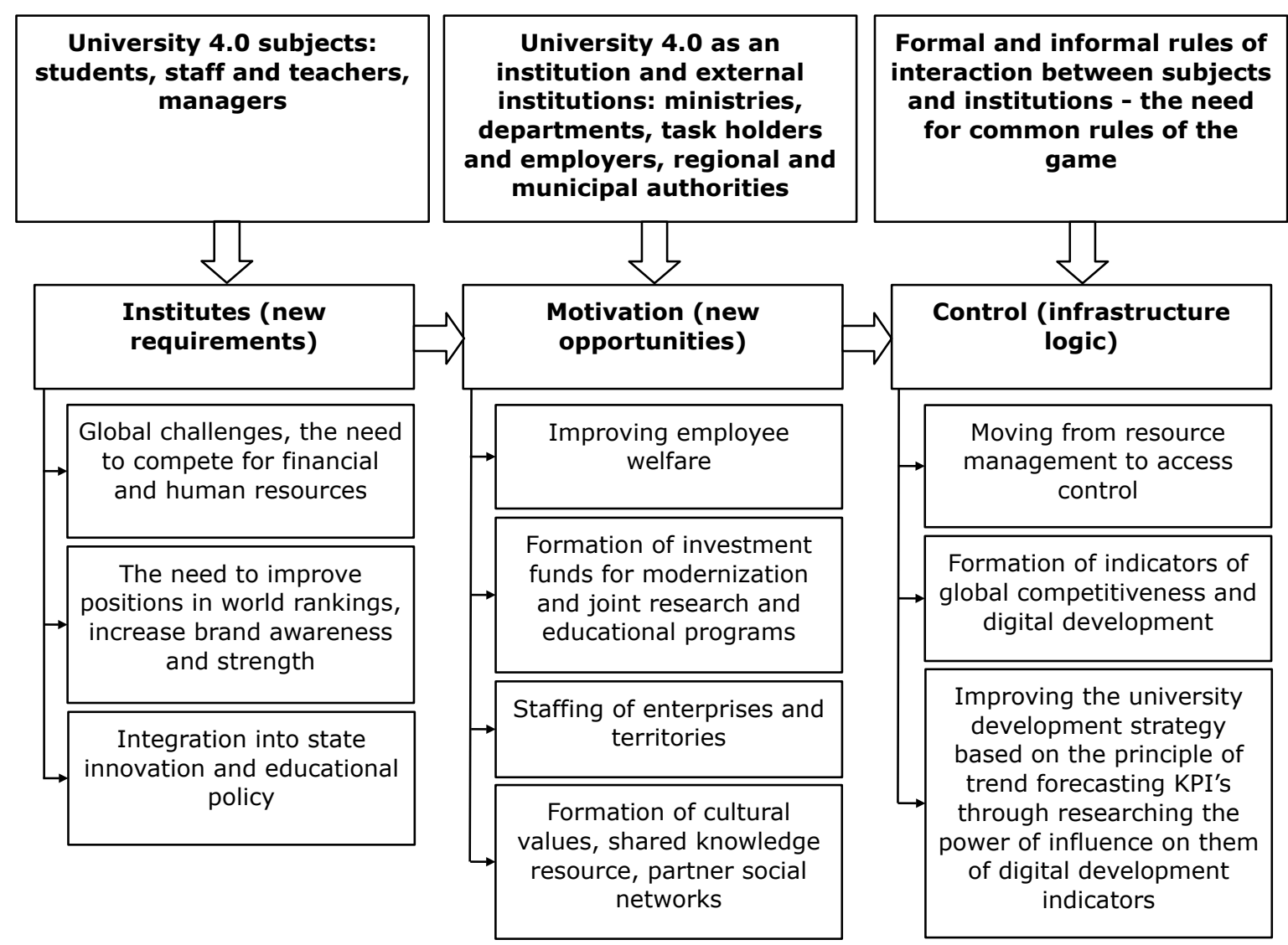

Fig. 2. The institutional mechanism for the development of the digital university model Source: developed by the authors.

The fact is that, in the authors' opinion, the main problem of the transition to the digital university model is systemic (institutional) obstacles. An analogy can be made with the installation of an onboard computer on the first car. Without the transition of the entire system (the formation of new institutions, conditions for motivating subjects and corresponding control procedures), it is impossible to launch a digital university model. It is imperative that all conflicting demands of university stakeholders can be met. It is impossible in the conditions of the functioning institutions. A new institutional mechanism is needed combining the rules of interaction (new requirements) and motivation (new opportunities) in order for the digital university model to start working. Otherwise, a simple imposition of digital technologies on traditional procedures and business processes will not bring the desired results.

The novelty of the authors' approach lies in the introduction into scientific circulation of a new concept - infrastructure logic, which acts as a connecting element between new requirements (formed through institutions) and new opportunities (determined by motivation), as an incentive to follow the new rules of the game, as an instrument of built-in control in the institutional mechanism of transition to a digital university model.

Each of the subjects associated with a digital university should be motivated to work according to new rules and new principles controlled by infrastructure logic. Students should benefit from new knowledge and skills acquired through new digital technologies and through participation in the translation of innovations in the real sector of the economy. Employees should improve their wellbeing through participation in new projects, refresher courses, distance learning through the MOOC, in the formation of research teams in the shortest possible time and taking into account the mobility and flexibility of the workload. At the same time, routine and bureaucratic procedures 
should be transferred to an automatic digital format. A digital university teacher should be engaged in creative work and scientific research as much as possible. The university administration should be able to create investment funds for the modernization of the university and the organization of high-tech broadcast laboratories. Third-party enterprises and the administration of the territory should be able to obtain the best and most professional personnel to solve the problems of the real sector of the economy. At the same time, such an effective institutional environment created according to a new infrastructure logic, will contribute to the formation of promising cultural values, a common resource of knowledge and partner social networks. Only after that will the transition to the digital university model be possible.

Our proposed concept for the formation of indicators of digital development of a modern university is shown in Fig. 2.

The implementation of the proposed concept will make it possible to remove the previously identified contradictions between the participants in university activities and ensure the formation of indicators of the digital development of the university, ensuring the necessary correspondence of the quality of the university's functioning to the requirements formed in the new, sixth, technological order.

\section{Discussion}

A rather serious problem of managing the development of a university, including its digital development, is elaborating a system of indicators. They should take into account, on the one hand, the need to increase the ranking of the university, and on the other hand, they should correspond to global trends in the development of science, education and production (Yakovlev et al., 2020).

In turn, this system of indicators through the method of strategic planning is incorporated in the university management system. Adjustment of indicators of strategic development of the university should take into account changes in the rules of behavior and motivation of the subjects of the university and its partners (Al-Mansoori and Koç, 2019).

In other words, digital development indicators should not be out of touch with reality. They should reflect the current state of digital development institutions and their future transformation in line with global trends. As scientists note, the education system formed in the previous technological order does not meet the needs of modern society (Kuznetsov, 2019). Accordingly, we need more adequate institutions and indicators of digital development of universities in modern conditions.

The literature pays considerable attention to new principles of digital development, which should be taken into account in the university digital development strategy (Frolova et al., 2020). Scientists identify such principles as the formation of institutional conditions for supporting digital innovations, taking into account situational factors, resource support of educational organizations, the priority of personal interests (suject-centered approach). We agree with this opinion and attach deeper meaning to these recommendations. These recommendations should fit the institutional mechanism of digital development of the university, should be interrelated with motivation and control mechanisms (by infrastructure logic).

From our point of view, the main principle is the transition from resource management to access control. This is justified by the fact that the key resources of a digital university are intangible assets. The growth in the use of intangible assets, in contrast to tangible ones, leads to an increase in their value and an increase in the common resource of knowledge (Dyatlov, 2017). At the same time, the formation of networked intellectual capital leads to the emergence of a new system of e- 
neural network education in the 21st century. We agree with this statement and focus on the institutional preparation of such a transformation of education. This will help avoid the risks of degradation of the national educational system.

Moving from asset management to access control will make the response to global challenges instantaneous. This approach presupposes the development of a new university management policy that will reduce the time for accessing the network resources of the university and its partners with the required level of security and compliance with the legislation on trade secrets and personal data. Scientists note that maintaining a high level of information security is a difficult task and depends on many factors (Moukhliss et al., 2019). From the point of view of our research, ensuring information security is a later stage after the development of the concept of a uniform institutional agreement for all participants in the digital transformation of the university.

Different opinions are expressed about the requirements for modern digital infrastructure at the university. For example, scientists point out that it is necessary to develop non-linear educational models and a flexible dynamic approach to the educational environment (Arseniev et al., 2019). This fully confirms our position. In our opinion, a digital university is characterized by new infrastructure requirements: openness, accessibility, mobility, flexibility, dispatch.

This approach will help overcome the differences in the requirements of various university stakeholders (students, teachers, government agencies, private enterprises). Scientists note that the Russian policy of managing digitalization is characterized by spontaneity and a lack of coordinated actions on the part of the state (Ilyina et al., 2019). This adds even more contradictions in the rules of conduct and the motivation of various stakeholders of the university. Based on the institutional analysis of the behavior of various stakeholders of the university, a new concept has been developed, characteristic of the digital university model - infrastructure logic.

The preparation of a digital development strategy for a university involves clarification of goals and objectives, their matching by the types of activities of the university and its structural divisions, the formation of a set of measures, joint research, conferences, laboratories, the implementation of national projects, advanced training and retraining of personnel (Dneprovskaya, 2018).

It is necessary to prepare personnel to work in new conditions, the conditions of development of a modern digital university model. The introduction of the digital university model requires administrative and organizational assistance on the part of the university management (Tømte et al., 2019).

Thus, the main results obtained in our study coincide with the opinions of many scientists, complement them and expand the possibilities for further research of the digital university 4.0 model.

\section{Insights and recommendations}

The key insight of the study is that the existing institutions (formal and informal rules of interaction) do not correspond to the global objectives of digital development. For the transition to a digital university model, it is necessary to discard the established routines and form new institutions that contribute to the effective use of digital technologies.

Another identified problem is the mismatch of interests and requirements of all participants in the digital university model (internal and external stakeholders). This problem must be solved in a comprehensive manner with the participation of the state and private entrepreneurs (investors) interested in providing their business with professional personnel and new technologies. 
The formation of a unified institutional agreement for the university stakeholders is to be facilitated by the approach developed by the authors - infrastructure logic. This phenomenon acts as a tool for monitoring the compliance of new institutions and motivations with the tasks of digital development. Infrastructure logic, with a whole toolkit of the necessary principles and requirements for organizing digitalization processes at the university, will discard all unnecessary, outdated institutions that hinder the implementation of global tasks of digital development.

The most important principle of infrastructure logic, developed by the authors, is the transition from resource management to access control. This will provide an adaptive and quick response to global challenges, increase the efficiency of educational, research and business activities of the university. Another principle of infrastructure logic is interaction in a partner digital university network, where participants can access the most advanced technologies, laboratory research, intelligent databases in the OpenSpace format.

Other principles of infrastructure logic are the independence of the formation of the scientific, educational and innovation agenda; focusing the university on global challenges and shaping development priorities on this basis; involvement in specialized international networks, collaborations and communities; flexibility and adaptability in response to changes in the internal and external environment.

And the last, but not the least, is the task of developing a system of indicators for the digital development of the university. These indicators should reflect the effectiveness of the implementation of the principles of infrastructure logic. Evaluating these indicators, it will be possible to analyze the quality of new institutions and motivations in terms of their compliance with the tasks of digital development.

Adjustment of the development strategy of the University 4.0, taking into account new indicators of digital development, should be constant and progressive.

\section{Conclusion}

First of all, it is necessary to develop a Concept for the digitalization of the education system and economy. The digital divide between universities must be closed. Since a digital university is, first of all, an element of the overall digital educational system. Without a common digital bank of resources, data, knowledge, universities will not be able to become digital.

The application of the concept of the development of the digital university model developed by the authors will make it possible to identify the most effective institutions (interaction rules) of all subjects of an educational institution and its partners in the context of the development of the digital university model.

This task is most urgent today. Its solution will stipulate Russian universities and enterprises to reach the world level of competitiveness, to switch to the new technological order that provides the economy with modern production technologies, products of current and long-term consumption, with modern high-tech jobs. This will generally revive the market economy, expand its export potential and domestic demand, fill the budget with tax revenues, and ensure that the state can fulfill its social obligations to the population.

This task should have a more long-term and large-scale solution associated with the integration of digital universities into the national innovation system and, accordingly, into the national digital economy. 


\section{Acknowledgments}

The reported study was funded by RFBR, project number 19-29-07037.

\section{References}

Al-Mansoori, R. S., \& Koç, M. (2019). Transformational leadership, systems, and intrinsic motivation impacts on innovation in higher education institutions: Faculty perspectives in engineering colleges. Sustainability (Switzerland), 11(15), Art. 4072. doi:10.3390/su11154072

Arseniev, D. G., Trostinskaya, I. R., Pozdeeva, E. G., \& Evseeva, L. I. (2019). Processes of changes in the educational environment under the influence of digital technologies. Paper presented at the ACM International Conference Proceeding Series. Art. 3377547. doi:10.1145/3372177.3377547

Barabanova, S. V., Kaybiyaynen, A. A., \& Kraysman, N. V. (2019). Digitalization of education in the global context. Vysshee Obrazovanie $v$ Rossii, 28(1), 94-103. doi:10.31992/0869-3617-2019-28-1-94-103

Baumol, U., \& Bockshecker, A. (2017). Evolutionary change of higher education driven by digitalization. Paper presented at the 2017 16th International Conference on Information Technology Based Higher Education and Training, ITHET 2017, doi:10.1109/ITHET.2017.8067811

Bolgova, E. V., Grodskaya, G. N., \& Kurnikova, M. V. (2020). The model for meeting digital economy needs for higher education programs. Advances in Intelligent Systems and Computing, 908, 542-556. doi: $10.1007 / 978-3-030-11367-4 \_54$

Crittenden, W. F., Biel, I. K., \& Lovely, W. A.,III. (2019). Embracing digitalization: Student learning and new technologies. Journal of Marketing Education, 41(1), 5-14. doi:10.1177/0273475318820895

Demichev I.V. (2021). Virtuality and Networking: About the Socio-Cultural Communities of the Information Age (Answer to M.G. Bresler's Monograph 'The Ontology of Network Existence'). Sovremennye issledovania socialnyh problem [Modern Studies of Social Issues], vol. 13, no. 2, pp. 14-37, doi: https://doi.org/ 10.12731/2077-1770-2021-13-2-14-37

Díaz, D., \& Boj, C. (2019). Artistic practices in the age of the datacene data biography: Digital traces to biographically explore personal identity. Artnodes, 2019(24), 121-133. doi:10.7238/a.v0i24.3293

Dneprovskaya, N. V. (2018). Assessment of the readiness of Russian higher education for the digital economy. Statistics and economics, 4, 16-28. Retrieved from: https://cyberleninka.ru/article/n/otsenkagotovnosti-rossiyskogo-vysshego-obrazovaniya-k-tsifrovoy-ekonomike

Dyatlov, S. A. (2017). E-neural network education in the digital era: theory and practice. Innovations. 8(226), 91-95. Retrieved from: https://cyberleninka.ru/article/n/eneyrosetevoe-obrazovanie-v-tsifrovuyuepohu-teoriya-i-praktika

Evans-Amalu, K., \& Claravall, E. (2021). Inclusive Online Teaching and Digital Learning: Lessons Learned in the Time of Pandemic and Beyond. Journal Of Curriculum Studies Research, 3(1), i-iii. https://doi.org/ $10.46303 /$ jcsr. 2021.4

Ferlie, E., \& Trenholm, S. (2019). Exploring new organisational forms in english higher education: A think piece. Higher Education, 77(2), 229-245. doi:10.1007/s10734-018-0269-7

Fligstein, N. (1996). Markets as politics: A political-cultural approach to market institutions. American Sociological Review, 61(4), 656-673. doi:10.2307/2096398

Frolova, E. V., Rogach, O. V., \& Ryabova, T. M. (2020). Digitalization of education in modern scientific discourse: New trends and risks analysis. European Journal of Contemporary Education, 9(2), 331-336. doi: $10.13187 /$ ejced.2020.2.331 
Ilyina, E. A., Shchiptsova, A. V., Poverinov, I. E., Grigoreva, S. V., Gorshkova, N. K., \& Fisunov, P. A. (2019). Features of the development of the digital educational environment in russia. International Journal of Higher Education, 8(7), 121-131. doi:10.5430/ijhe.v8n7p121

Irodov, M. I., \& Korechkov, Yu. V. (2018). Higher education in the digital economy. Bulletin of Eurasian Science, 10(1), 13. Retrieved from: https://cyberleninka.ru/article/n/vysshee-obrazovanie-v-tsifrovoyekonomike

Korableva, O., Durand, T., Kalimullina, O., \& Stepanova, I. (2019). Studying user satisfaction with the MOOC platform interfaces using the example of coursera and open education platforms. Paper presented at the ACM International Conference Proceeding Series, 26-30. doi:10.1145/3322134.3322139

Kuznetsov, N. V. (2019). Online education: key trends and obstacles. E-Management, 2(1), 19-25. Retrieved from: https://cyberleninka.ru/article/n/onlayn-obrazovanie-klyuchevye-trendy-i-prepyatstviya

Moukhliss, G., Filali Hilali, R., \& Belhadaoui, H. (2019). A smart card digital identity check model for university services access. Paper presented at the ACM International Conference Proceeding Series, Part F148154. Art. 67. doi:10.1145/3320326.3320401

Mukhomorova, I. V., Akopova, E. S., Pavlova, L. K., \& Sheveleva, V. V. (2020). Global competitiveness of the digital economy: The problem of measuring and management. Lecture Notes in Networks and Systems, 87, 23-29. doi:10.1007/978-3-030-29586-8_3

Nesterenko, A. N. (1997). Current state and main problems of institutional-evolutionary theory. Problems of Economics, 3, 48.

North, D. (2012). Institutions, Institutional Change and Economic Performance. United Kingdom, Cambridge: Cambridge University Press.

Nurgaliev, A. S., Vershinin, I. S., \& Minyazev, R. S. (2019). Concept and implementation of blockchain demonstration unit within the smart grid. Paper presented at the Proceedings of the 2019 International Conference on Industrial Engineering, Applications and Manufacturing, ICIEAM 2019, Art. 8742927.

Perez Gama, J. A., Vega Vega, A., \& Neira Aponte, M. (2018). University digital transformation intelligent architecture: A dual model, methods and applications. Paper presented at the Proceedings of the LACCEI International Multi-Conference for Engineering, Education and Technology, 2018-July. doi:10.18687/LACCEI2018.1.1.274

Safiullin, M. R., Akhmetshin, E. M. \& Vasilev, V. L. (2019). Production of Indicators for Evaluation of Digital Transformation of Modern University. International Journal of Engineering and Advanced Technology, 9(1), 7399-7402. doi:10.35940/ijeat.A3100.109119

Semenov V.A. (2021). Features of the Use of Distance Learning Technologies and Educational Materials in Geography Lessons. Russian Journal of Education and Psychology, vol. 12, no. 2, pp. 21-38, doi: https://doi.org/10.12731/2658-4034-2021-12-2-21-38

Tømte, C. E., Fossland, T., Aamodt, P. O., \& Degn, L. (2019). Digitalisation in higher education: Mapping institutional approaches for teaching and learning. Quality in Higher Education, 25(1), 98-114. doi: $10.1080 / 13538322.2019 .1603611$

Vasiliev, V. L. (2014). Levels of economic security: analysis of methodological approaches. Bulletin of Kazan Technological University, 17(18), 272-276. Retrieved from: https://elibrary.ru/item.asp?id=22480239

Williams, T., McIntosh, R., \& Russell, W. (2021). Equity in Distance Education During COVID-19. Research in Social Sciences and Technology, 6(1), 1-24. https://doi.org/10.46303/ressat.2021.1

Yakovlev, G. I., Streltsov, A. V., Izmailov, A. M., Ermolina, L. V., \& Sunteev, A. N. (2020). Specific features of formation of value creation chains in industry and entrepreneurship in the digital economy. Lecture Notes in Networks and Systems, 87, 677-689. doi:10.1007/978-3-030-29586-8_79

Yli-Viitala, P., Arrasvuori, J., Silveston-Keith, R., Kuusisto, J., \& Kantola, J. (2020). Digitalisation as a driver of industrial renewal-perception and qualitative evidence from the USA. Theoretical Issues in Ergonomics Science, 21(1), 1-21. doi:10.1080/1463922X.2019.1621404 
Zelentsova, L. S. (2018). Development of a flexible higher education system in the era of the digital economy. Russia: development trends and prospects, 13(1). Retrieved from: https://cyberleninka.ru/article/n/ razvitie-sistemy-gibkogo-vysshego-obrazovaniya-v-epohu-tsifrovoy-ekonomiki

Zelentsova, L., \& Tikhonov, A. (2020). A methodology for assessing the innovative potential of a high-tech organization under the economy digitalization impact. Quality - Access to Success, 21(174), 7-13. 